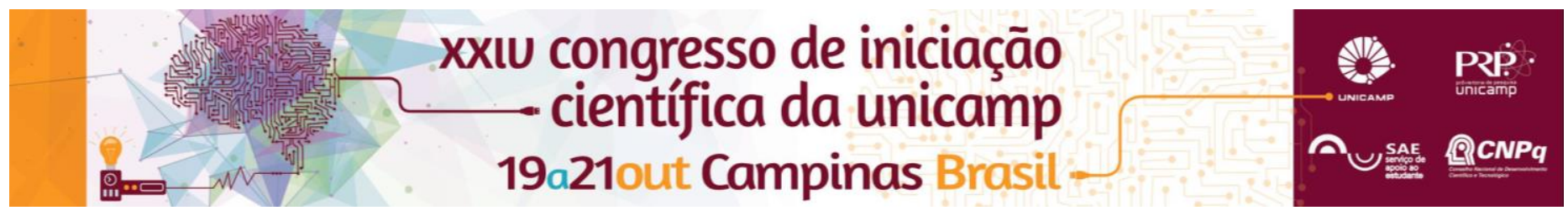

\title{
O CONCEITO DE INTENCIONALIDADE: REALISMO DIRETO E REPRESENTACIONALISMO
}

\author{
Márcio A. D. Custódio, Danilo R. Furlan*
}

\begin{abstract}
Resumo
As pesquisas por mim desenvolvidas detiveram-se inicialmente no escrutínio da bibliografia primária contida neste projeto com a análise exegética do "Comentário ao De Anima" e da "Suma de Teologia" no que diz respeito às principais atribuições feitas por Tomás de Aquino acerca da alma enquanto forma do corpo e princípio de operação intelectual no homem. É importante frisar que mesmo a alma estando unida ao corpo e operando conjuntamente a ele, subsiste ontologicamente por si como substância incorruptível e garantidora de todos os atos corporais. Meu interesse principal concentrou-se no papel desempenhado pelo intelecto agente relativo ao ato da abstração do fantasma da imaginação, condição sine qua non que garante o conhecimento dos objetos singulares quando os próprios dados sensoriais do objeto assimilado pelos sentidos tornam-se desprovidos de materialidade e posteriormente, inteligidos segundo a universalidade da forma extraída do próprio fantasma. Assim, o ato de inteligir e o produto da cognição humana constituem a querela entre as posições a) representacionalista, ao sustentar a grosso modo uma relação triádica do conhecimento, na qual os estados mentais constituem o primeiro objeto da cognição; e b) realista direta, que trata o próprio objeto como aquilo que primeiramente é conhecido pelo intelecto, cuja forma seja a mesma que constitua hiliemorficamente a coisa extramental, e que está intencionalmente na espécie inteligível presente no intelecto. A noção de similitude vinculada à noção de representação parece ser um dos pontos mais discordes entre as chaves de leitura representacionalista e realista direta. Um dos representantes do realismo direto, Dominik Perler1, sustenta que dois conceitos são blocos estruturantes do mundo e do valor de verdade sobre o conhecimento do mundo, a saber, os conceitos de identidade e de essência. Estes se vinculam ao tema da intencionalidade a partir da noção de conhecimento por assimilação da forma dos objetos extramentais: para os realistas, portanto, não há um conceito que intermedeie o conhecimento do objeto extramental pelo sujeito que intelige algo, já que a noção de similitude seria um tipo de compartilhamento de formas, ao passo que para os representacionalistas na visão de Raul Landim Filho2, a inteligibilidade da espécie inteligível só se perfaz na conversão ao fantasma com o conhecimento indireto do singular com o cumprimento do ato de intelecção, dado que o objeto próprio do intelecto é a quididade das coisas materiais, isto é, a universalidade e não a espécie inteligível por si, considerada exclusivamente como o princípio do ato de intelecção inicialmente abstraída do fantasma.
\end{abstract}

\section{Palavras-chave:}

Abstração, Assimilação, Teoria do conhecimento

\section{Introdução}

Neste projeto de pesquisa intencionei me ocupar prioritariamente do processo de abstração das espécies inteligíveis dentre as três etapas cognitivas da constituição do conhecimento na teoria epistemológica de Tomás de Aquino, onde incide as principais divergências entre o representacionalismo e o realismo direto. Considerei conveniente correlacionar a estrutura ontológica do mundo com o modo pelo qual o intelecto, que é potência e também atividade, conhece a natureza das substâncias naturais, entendendo que as coisas existem segundo uma dada matéria e uma forma específica e que estão submetidas ao trânsito da potência para o ato. Tudo isso para iluminar o que se quer dizer por assimilação e por intencionalidade da forma presente no intelecto.

\section{Resultados e Discussão}

Minhas pesquisas foram embasadas na leitura sistemática dos textos de Tomás de Aquino coligidos para análise, assim como aqueles diretamente vinculados ao tema proposto. Ademais, a bibliografia secundária contida no projeto foi sistematicamente consultada dentro da pertinência do tema. Nas obras de Tomás, utilizei de traduções para o português, inglês, espanhol, cotejando o texto original latino. Os resultados parciais da pesquisa

DOI: 10.19146/pibic-2016-51503 foram minuciosamente discutidos com o orientador e expostos em seminários internos do grupo de pesquisa. Parte do resultado final do trabalho deverá ser apresentado no XVIII Encontro de Pesquisa na graduação de Filosofia da Unicamp.

\section{Conclusões}

O desenvolvimento deste projeto foi de grande valia para o meu progresso acadêmico no tange ao comprometimento com a pesquisa, à redação de artigos e relatórios, mas especialmente ao entendimento mais aprofundado de um tema filosófico revestido de contemporaneidade que envolve a teoria da inteligibilidade em Tomás de Aquino e seu grande aporte teórico.

\section{Agradecimentos}

Agradeço cordialmente ao Prof. Dr. Márcio A. D. Custódio pela orientação neste trabalho e aos membros do grupo de estudos Revolução Científicos dos séculos XVI e XVII: Origens, Influências e Bases Científicas e Filosóficas pelas gentis ponderações e instruções.

\footnotetext{
${ }^{1}$ Perler, D. Essentialism and Direct Realism: Some Late Medieval Perspectives. Kluwer Academic, 111-122, 2000.

${ }^{2}$ Landim Filho, R. Conceito e objeto em Tomás de Aquino. In: Analytica (UFRJ),v.14,65-88, 2010.
} 